\title{
Curcuma Longa Abolishes Phenylephrine-Induced Contractions in Isolated Aortic Artery of Rats
}

Natacha Pinheiro Melo Brozzo, ${ }^{\circledR}$ Efraim dos Santos Ferreira, ${ }^{1 \oplus}$ Eduardo Andrade Gonçalves, ${ }^{1}$ Dionatas Ulises de Oliveira Meneguetti, ${ }^{1,3 \oplus}$ Delano Aníbal da Silva, ${ }^{1,2}{ }^{\circledR}$ Renildo Moura da Cunha ${ }^{\circledR}$

Universidade Federal do Acre, Rio Branco, ${ }^{1}$ AC - Brazil

Faculdade Meta (FAMETA), ${ }^{2}$ Rio Branco, AC-Brazil

Colégio de Aplicação da UFAC, ${ }^{3}$ Rio Branco, AC - Brazil

\section{Abstract}

Background: Curcuma longa has biological effects. Its cardiovascular activities are yet to be scientifically studied.

Objectives: To investigate the vasorelaxant effects of the aqueous extract of Curcuma longa (AECL).

Methods: Aortic annuli of normotensive rats, with or without endothelium, were set up in a data storage system with nutrient solution in recipients, with scientifically recommended temperature, aeration and tension. Over contraction by Phenylephrine, the AECL $(1,3,10,30,100,300$ and $1000 \mu \mathrm{g} / \mathrm{mL})$ was incubated before and after incubation with atropine or L-name or indomethacin. An AECL concentration-response curve was also built over contractions caused by elevation of extracellular $\mathrm{K}^{+}$. Data were significant when $\mathrm{p}<0.05$, with GraphPad Prism 6.0 software resolutions.

Results: The AECL induced 100\% vasorelaxation also in the endothelium-free annuli. The part of the endotheliumdependent effect had $\mathrm{EC}_{50}=4.32 \pm 0.05 \mu \mathrm{g} / \mathrm{mL}$. With inhibition of $\mathrm{NO}$ production, the $\mathrm{EC}_{50}$ increased to $126.50 \pm 2.35 \mu \mathrm{g} / \mathrm{mL}$; after inhibition of prostacyclin production, to $124.6 \pm 0.05 \mu \mathrm{g} / \mathrm{mL}$; and after muscarinic blockade, to $437.10 \pm 0.2 \mu \mathrm{g} / \mathrm{mL}$. Opening of $\mathrm{K}^{+}$channels (relaxation of $56.98 \%$ ) and VOCC blockade (relaxation of $31.56 \%$ ) were evident.

Conclusion: AECL induced significant vasorelaxation, being more significant in the presence of endothelium. The muscarinic pathway seems to be the main one involved in this effect, followed by the NO production and prostacyclin pathways. The activity in $\mathrm{K}^{+}$channels by AECL was more significant than its VOCC blockade. The use of other models and tools to study action mechanisms will be important and elucidating. (Int J Cardiovasc Sci. 2019;32(3)207-216)

Keywords: Curcuma/adverse effects; Crocus; Receptors, Muscarinic; Vasodilator Agents; Cardiotonic Agents; Antioxidants; Hypertension.

\section{Introduction}

According to the World Health Organization (WHO) and the Pan American Health Organization (PAHO), heart diseases are one of the major causes of death worldwide1 and in low- and middle-income countries, more than three-quarters of the deaths are due to cardiovascular diseases. ${ }^{1,2}$

Hypertension is the main risk factor for the development of cardiovascular diseases, affecting more than one billion people worldwide. ${ }^{3-5}$ The use of allopathic drugs has been the main type of therapy used to fight hypertension and, consequently, all the other diseases that result from it, even though it is known that one of the major problems of this treatment option are its side effects. ${ }^{5}$

Recently, more attention has been paid to the use of medicinal plants to attenuate the damage of several diseases, including arterial hypertension. ${ }^{6,7}$ The rhizome of Curcuma longa Linnaeus, which belongs to the Zingiberaceae family of Malay-Indigenous origin, ${ }^{8}$ popularly known as Yellow Ginger or Saffron, was used only as a food dye in many countries, and its 
leaves were used to wrap fish and to give aroma and flavor to the food preparation. ${ }^{9}$ More recent studies report cardioprotective, ${ }^{10}$ anti-inflammatory, ${ }^{8,11}$ antimicrobial, ${ }^{12}$ antiproliferative, ${ }^{12}$ antioxidant, ${ }^{13}$ antifungal ${ }^{14}$ and vasorelaxant ${ }^{15}$ properties. There is still little available information on its mechanism of action and effects on the cardiovascular system. The present study aims to investigate AECL action on vascular contractions induced in the isolated aortic artery of normotensive rats. Preclinical scientific studies of this nature may not only serve as the basis to obtain alternative phytomedicinal sources of attenuation of cardiovascular system-related diseases among the traditional needy populations, but they can, primarily, indicate to the scientific community and to the pharmaceutical industry new sources of raw materials to obtain medicinal principles available in nature, which already have discreet and crucial scientific information.

\section{Methods}

Preparation of the Curcuma longa $L$ extract

The plant was collected in a private property located in Vila Campinas, Ramal das chácaras, in the municipality of Plácido de Castro, in the state of Acre, northern Brazil. A voucher specimen was deposited at the herbarium of Universidade Federal do Acre (UFAC), under number 20002. The healthy-looking leaves were selected, washed under running water and placed in a greenhouse at $40^{\circ} \mathrm{C}$ for 48 hours, where dehydration occurred, and then they were ground in a knife-type mill at the Food Technology Unit (UTAL) of Universidade Federal do Acre. To obtain the aqueous extract of Curcuma Longa (AECL), 4 liters of distilled water with 370 grams of the crushed plant material were placed in a heated balloon flask for 10 minutes at $100^{\circ} \mathrm{C}$, followed by filtration. The filtrate was lyophilized, stored in an amber glass vial and kept under refrigeration at $4^{\circ} \mathrm{C}$.

\section{Drugs}

Phenylephrine hydrochloride (PHE), atropine sulfate, acetylcholine chloride (ACh), NG-nitro-L-argininemethyl ester (L-NAME) and Indomethacin were used, all from SIGMA-ALDRICH. Stock solutions of indomethacin were dissolved together with $5 \mathrm{~N}$ sodium bicarbonate $\left(\mathrm{NaHCO}_{3}\right)$ in distilled water. The other drugs, including AECL and solutions, were diluted in distilled water. The perfusion medium used was Krebs-Henseleit nutrient solution, containing (in $\mathrm{mM}$ ): $\mathrm{NaCl}$ (118.4); $\mathrm{KCl}$ (4.75); $\mathrm{KH}_{2} \mathrm{PO}_{4}$ (1.18); $\mathrm{NaHCO}_{3}(25) ; \mathrm{MgSO}_{4}$ (1.18); $\mathrm{CaCl}_{2}$ (1.9) and glucose (5). The nutrient solution had the $\mathrm{pH}$ adjusted with $1 \mathrm{M} \mathrm{HCl}$ or $1 \mathrm{M} \mathrm{NaOH}$ to 7.3 and 7.4. The AECL concentrations that were cumulatively used in all experiments were, invariably, 1, 3, 10, 30, 100, 300 and $1000 \mu \mathrm{g} / \mathrm{mL}$. PHE and ACh concentrations were $0.1 \mu \mathrm{M}$ in all experimental protocols.

\section{Toxicity Assay}

To assess possible toxic effects of the AECL, a Fixed Dose Procedure (FDP) parameter was used according to the Acute Toxic Class Method of 2001 (OECD). ${ }^{16}$ In this test, mice fasted for 12 hours prior to the experiment and were divided into 3 groups (n sample $=6$, used for convenience): group 1 (control), 2 (dose of $2000 \mathrm{mg} / \mathrm{kg}$ ) and 3 (dose of $5000 \mathrm{mg} / \mathrm{kg}$ ), comprising a total number of 18 animals. Only saline solution was administered in group 1, and in group 2, the dose of $2000 \mathrm{mg} / \mathrm{kg}$. In the absence of lethality or toxicity, then the dose of $5000 \mathrm{mg} / \mathrm{kg}$ was administered in group 3. The toxicity assessed by observing the following behavioral parameters, described in the hippocratic test of Malone and Robichaud ${ }^{17}$ are: attention, alertness, analgesia, spontaneous motor activity, locomotion, lack of appetite, apathy, response to tact, piloerection, ptosis, respiratory rate, cyanosis, stereotypy, contortion, aggressiveness, ataxia, posture, sweating, urination, diarrhea and seizure.

The parameters were observed every 60 minutes for 3 hours after the administration of the extract. Subsequently, they were also observed after 24, 48, and 72 hours and on the $15^{\text {th }}$ day. At the end of the observations all the animals were euthanized according to the euthanasia practice guidelines of the National Council for the Control of Animal Experimentation (Conselho Nacional de Controle de Experimentação Animal CONCEA). Traditional barbiturates and anesthetics were used for the euthanasia procedure, with a rapid, gentle effect and with minimal discomfort to the animals. These drugs are potent Central Nervous System depressants, of which effects are widely known and predictable.

Assessment of AECL activity in the annuli of isolated thoracic aorta of rats

A total of 14 rats were used in this study, resulting in 42 aortic annuli. Initially the annuli were divided into 
two groups $(n=6)$, being sufficient to perform in vitro experiments for each concentration of the same group with the same nature, defined as group 1 (annulus with present endothelium) and 2 (annulus without endothelium). Subsequently, the subgroups were divided into five groups $(\mathrm{n}=6)$ for the assessment of the verified action mechanism, namely: group 1.1 (L-NAME), group 1.2 (Indomethacin), group 1.3 (Atropine), group 2.1 (KCl $20)$ and group $2.2(\mathrm{KCl} 80)$.

\section{Preparation and setting-up of the vascular annulus}

Male rats of the Rattus norvegicus species, of the Wistar lineage, weighing 200-300 g, were euthanized by cervical dislocation and then a ventral incision was performed with opening of the rib cage by performing an excision in the sternum and part of the ribs, for visualization and removal of the intrathoracic organs. The thoracic aorta was removed and transferred to a Petri dish containing Krebs nutrient solution aerated by carbogenic mixture $\left(95 \% \mathrm{CO}_{2}+5 \% \mathrm{O}_{2}\right)$ and cleansed by removing the adipose tissue and connective tissue adhered to the artery segment. The artery segment was fractionated into $4 \mathrm{~mm}$-rings and set up, fixed between 2 small wire triangles. One side of one of the triangles was introduced into the annulus lumen, with the vertex opposite to the annulus, being fixed to the base of a thin metallic rod attached to the system, and the opposite vertex of the other triangle, by a cotton thread, attached to a isometric force transducer (AdInstruments).

The aorta preparations for all experiments were preliminarily stabilized for 1 hour in Krebs nutrient solution, with replacement of the solution every 15 minutes to eliminate and minimize metabolite effect; constant adjustment of the passive voltage applied to the annulus was also performed to $1 \mathrm{~g}$ (baseline initial tension), maintained at $37^{\circ} \mathrm{C}$ and continuously aerated by carbogen $\left(95 \% \mathrm{O}_{2}+5 \% \mathrm{CO}_{2}\right)$. The data on voltage variations, as a function of tissue reactivity to drug administration, were obtained after the conversion of the electrical signals captured by the transducer into digital signals and transmitted by an amplifier-recorder (AdInstruments). The variation records of the degree of contraction of the annulus smooth musculature were sent to a microcomputer, where they were processed and stored in the Protowin organ baths software (Pan Lab) for later analytical and statistical treatment.

All protocols were carried out according to the norms issued by the National Council for the Control of Animal
Experimentation (CONCEA) and approved by the Ethics Committee on Animal Use (Comitê de Ética no Uso de Animais - CEUA) of UFAC (Universidade Federal do Acre) under number 23107.018498 / 2016- 40.

Evaluation of the AECL activity in aortic annuli with and without endothelium contracted with phenylephrine

Immediately after the preparations' stabilization period, the presence $\left(\mathrm{E}^{+}\right)$or absence (E-) of functional endothelium in the annuli was verified by adding $\mathrm{ACh}$ on the plateau of the sustained tonic phase of the PHEinduced contraction, establishing as $\left(\mathrm{E}^{+}\right)$annuli those of which relaxation percentages induced by $\mathrm{ACh}$ were $\geq 70 \%$ and as (E-), those with $<5 \%$ of relaxation. The tissues prepared in the recipients were again contracted by PHE and, after five to seven minutes of sustained tonic phase contraction, increasing concentrations of $\operatorname{AECL}(1,3,10,30,100,300$ and $1000 \mu \mathrm{g} / \mathrm{mL})$ were cumulatively added to the preparations containing $\left(\mathrm{E}^{+}\right)$or (E-) annuli. The relaxation percentage was determined by comparing the PHE contraction values before and after the cumulative addition of the extract and also by calculating the EC50 values.

Evaluation of the AECL effect after inhibition of the enzymes of the nitric oxide (NO) production pathway, the prostacyclin (PGE2 and PGI2) production pathway and the endothelial muscarinic blockade

In annulus-containing preparations $\left(\mathrm{E}^{+}\right)$, the cumulative administration of AECL at the PHE-induced contraction plateau was performed before and after the L-NAME $(100 \mu \mathrm{M})$, and incubated for 30 minutes, for the evaluation of nitric oxide (NO) involvement in the AECL effect. To assess the involvement of prostacyclines, indomethacin $(10 \mu \mathrm{M})$, instead of L-NAME, was also incubated for 30 minutes. To verify the probable participation of muscarinic receptors, following the same experimental protocol, atropine incubation $(1 \mu \mathrm{M})$ was previously performed for 15 minutes, instead of the two enzyme inhibitors.

Evaluation of AECL activity in contracted aortic rings with depolarizing $\mathrm{KCl}$ solution

To evaluate the involvement of ion channels, experiments were performed using (E-) annuli. In these approaches, after stabilization of the preparations and other mandatory preliminary procedures, instead of 
contractions caused by PHE, contractions induced by increased $\mathrm{K}^{+}$concentrations in the bath - extracellular medium $\left(\left[\mathrm{K}^{+}\right] \mathrm{e}\right)$, were produced; these operations were performed with $20 \mathrm{mM} \mathrm{KCl}$ or $80 \mathrm{mM} \mathrm{KCl}$ solutions, in separate individual samples; at their plateaus, a cumulative administration of increasing concentrations of AECL was performed.

\section{Statistical analysis}

All points plotted in the graphs are expressed as mean \pm standard deviation (SD) and represent the individual experiments (control and treatments) (n sample = 6 , by convenience) for each one of them, performed individually. The nature of biological responsiveness and the biochemical processes triggered by the injection of exogenous substances and the reactivity due to the induction of endogenous releases, as well as considering the very nature of the crude extracts (consisting of many active principles), naturally justify the fact that the $\mathrm{EC}_{50}$ values resulting from the analyses on individual concentration-response curves were carried out through non-linear regression. The D'Agostino normality test was performed. As the data were normal, the two-way analysis of variance (ANOVA) was applied. Statistical differences between the means of the results were determined by the paired Student's $t$ test and when appropriate (for multiple comparisons). The authors did not observe limiting factors in this study. The analyses and representations were carried out with the software GraphPad Prism 6.0 (GraphPad Software Inc., San Diego, CA, USA), with significance being set at $\mathrm{p}<0.05$.

\section{Results}

\section{Toxicity}

None of the animals died or showed deleterious behavioral changes capable of compromising the limits of normality during the toxicity studies (data not shown). The group receiving the $2000 \mathrm{mg} / \mathrm{kg}$ dose, even up to the fifteenth day of observation, showed no alterations as a result of the treatment. At the dose of $5000 \mathrm{mg} / \mathrm{kg}$ there was mild sedation in the first hour after the extract administration in only one animal in the group. At the subsequent hours and days, none of the animals showed any behavioral change or died. Therefore, AECL did not show any alterations of clinical importance in the animals submitted to the treatments.
Influence of the vascular endothelium on AECL activity in isolated aortic artery annuli of normotensive rats pre-contracted with PHE

In $\mathrm{E}^{+}$annuli, the AECL abolished contractions induced by PHE, with an $\mathrm{EC}_{50}=4.32 \pm 0.05 \mu \mathrm{g} / \mathrm{mL}$. Significant vasorelaxation $(\mathrm{p}<0.01)$ occurred in a concentrationdependent manner. In the E- annuli, it also reached $100 \%$, but the AECL response was significantly $(p<0.01)$ modified by the removal of the vascular endothelium and $\mathrm{EC}_{50}$ increased to $134.20 \pm 1.80 \mu \mathrm{g} / \mathrm{mL}$, indicating that the effect of AECL strongly depends on factors derived from the vascular endothelium (Figure 1).

Involvement of NO in the AECL relaxant effect on isolated aortic artery annuli of normotensive rats pre-contracted with PHE

After inhibition of the NO synthesis enzyme by L-NAME, the AECL vasorelaxant effect on intact aorta annuli was significantly $(p<0.01)$ inhibited, an event evidenced by an increase in the $\mathrm{EC}_{50}$, from $4.32 \pm$ $0.05 \mu \mathrm{g} / \mathrm{mL}$ to $126.50 \pm 2.35 \mu \mathrm{g} / \mathrm{mL}$ (Figure 2), indicating clear involvement of the NO production pathway in the AECL effect.

Involvement of the prostacyclin production pathway in the AECL relaxant effect on isolated aortic artery annuli of normotensive rats pre-contracted with PHE

After blocking prostaglandin synthesis with indomethacin, the vasorelaxant response induced by AECL was significantly $(p<0.01)$ inhibited after indomethacin incubation, a fact disclosed by the $\mathrm{EC}_{50}$ elevation, from $4.32 \pm 0.05 \mu \mathrm{g} / \mathrm{mL}$ to $124.6 \pm$ $0.05 \mu \mathrm{g} / \mathrm{mL})$, suggesting that the AECL effect is also related to the prostacyclin production pathway (Figure 3).

Involvement of the muscarinic pathway in the AECL relaxant effect on isolated aortic artery annuli of normotensive rats pre-contracted with PHE

In this approach, the vasorelaxant response induced by AECL was the most significantly attenuated, as shown by the prominent $(\mathrm{p}<0.01)$ increase in $\mathrm{EC}_{50}$, from $4.32 \pm$ $0.05 \mu \mathrm{g} / \mathrm{mL}$ to $437.10 \pm 0.2 \mu \mathrm{g} / \mathrm{mL}$ (Figure 4 ). These data suggest that, of the investigated pathways, muscarinic receptors seem to be the most significantly implicated in the vasorelaxant effect induced by the AECL on the isolated thoracic aorta of rats. 


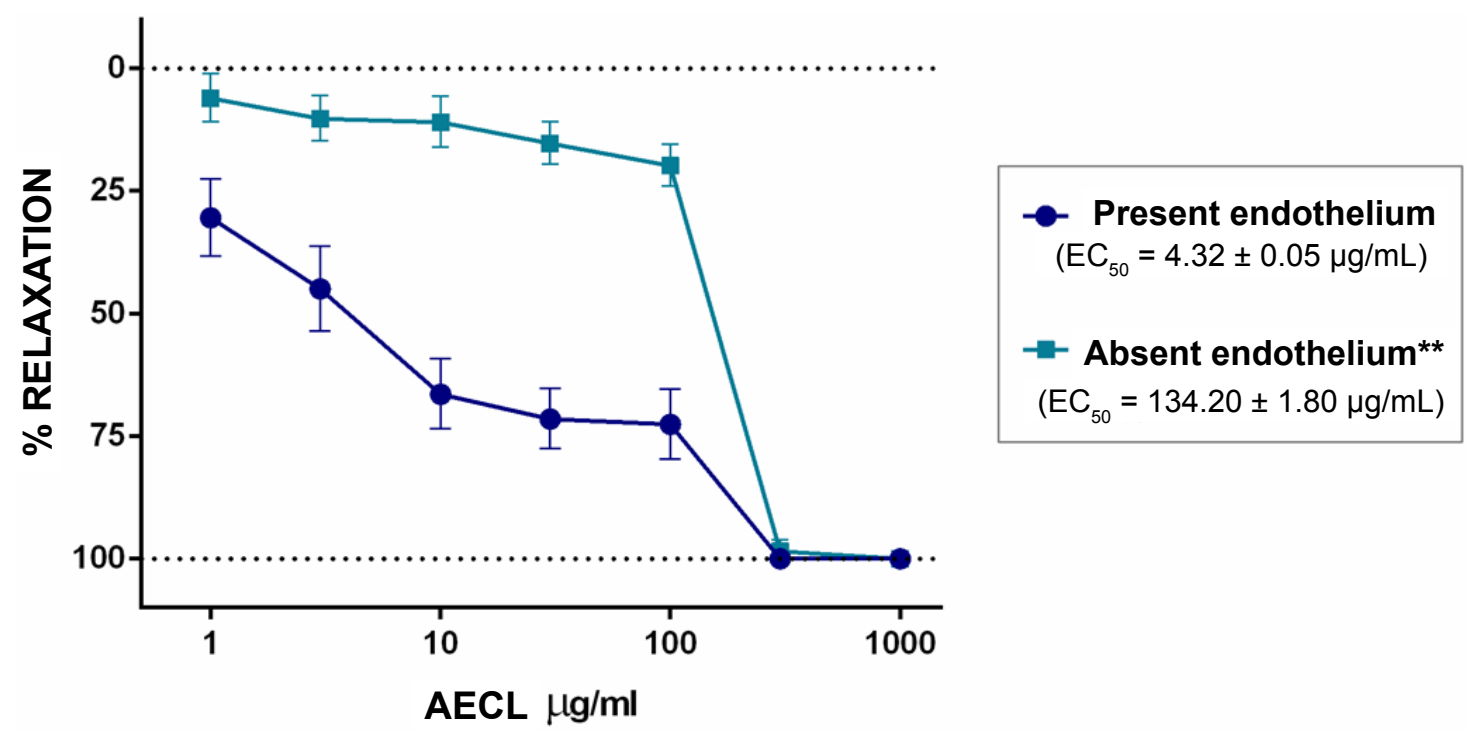

Figure 1 - Concentration-response curve for $\operatorname{CLAE}(1,3,10,30,100,300$ and $1000 \mu \mathrm{g} / \mathrm{mL})$ on PHE-induced contractions $(0.1 \mu M)$ in isolated aortic annuli of normotensive rats in the presence and absence of functional endothelium. The dots represent the mean \pm SD of the concentrations used with $n=6$ and ${ }^{* *}(p<0.01)$ versus $E^{+}$.

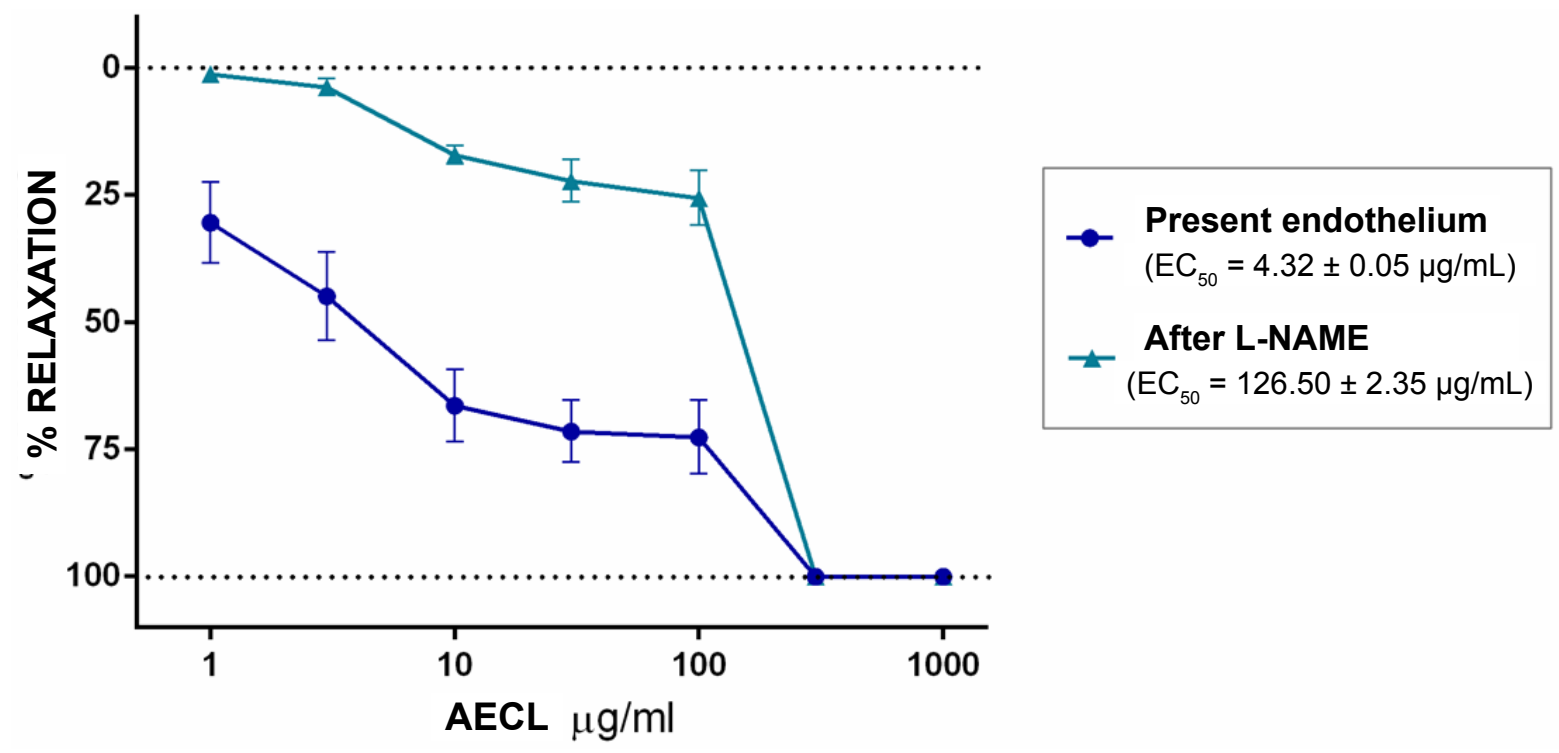

Figure 2 - Concentration-response curve for $\operatorname{CLAE}(1,3,10,30,100,300$ and $1000 \mu \mathrm{g} / \mathrm{mL})$ in rat isolated thoracic aorta annulus with intact endothelium and pre-contracted with PHE $(0.1 \mu \mathrm{M})$ before $\mathrm{E}^{+}$and after NO synthase inhibition. The dots represent the mean \pm SD of the concentrations used with $n=6$ and ${ }^{* *}(p<0.01)$ versus $E^{+}$. 


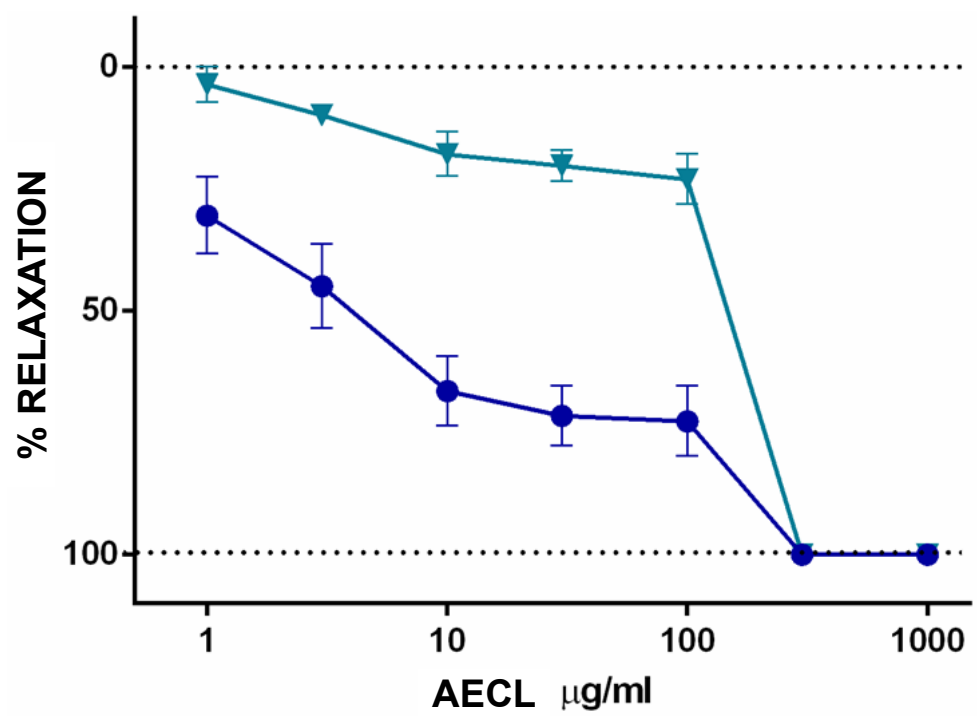

\section{Present endothelium}

$\left(\mathrm{EC}_{50}=4.32 \pm 0.07 \mu \mathrm{g} / \mathrm{mL}\right)$

\section{After Indomethacin**}

$\left(\mathrm{EC}_{50}=124.60 \pm 0.05 \mu \mathrm{g} / \mathrm{mL}\right)$

Figure 3 - Concentration-response curve for $\operatorname{CLAE}(1,3,10,30,100,300$ and $1000 \mu \mathrm{g} / \mathrm{mL})$ in rat isolated thoracic aorta annulus with intact endothelium and pre-contracted endothelium with PHE $(0.1 \mu \mathrm{M})$ before $E^{+}$and after cyclooxygenase-1 (COX-1) inhibition. The dots represent the mean $\pm S D$ of the concentrations used with $n=6$ and ${ }^{* *}(p<0.01)$ versus $E^{+}$.

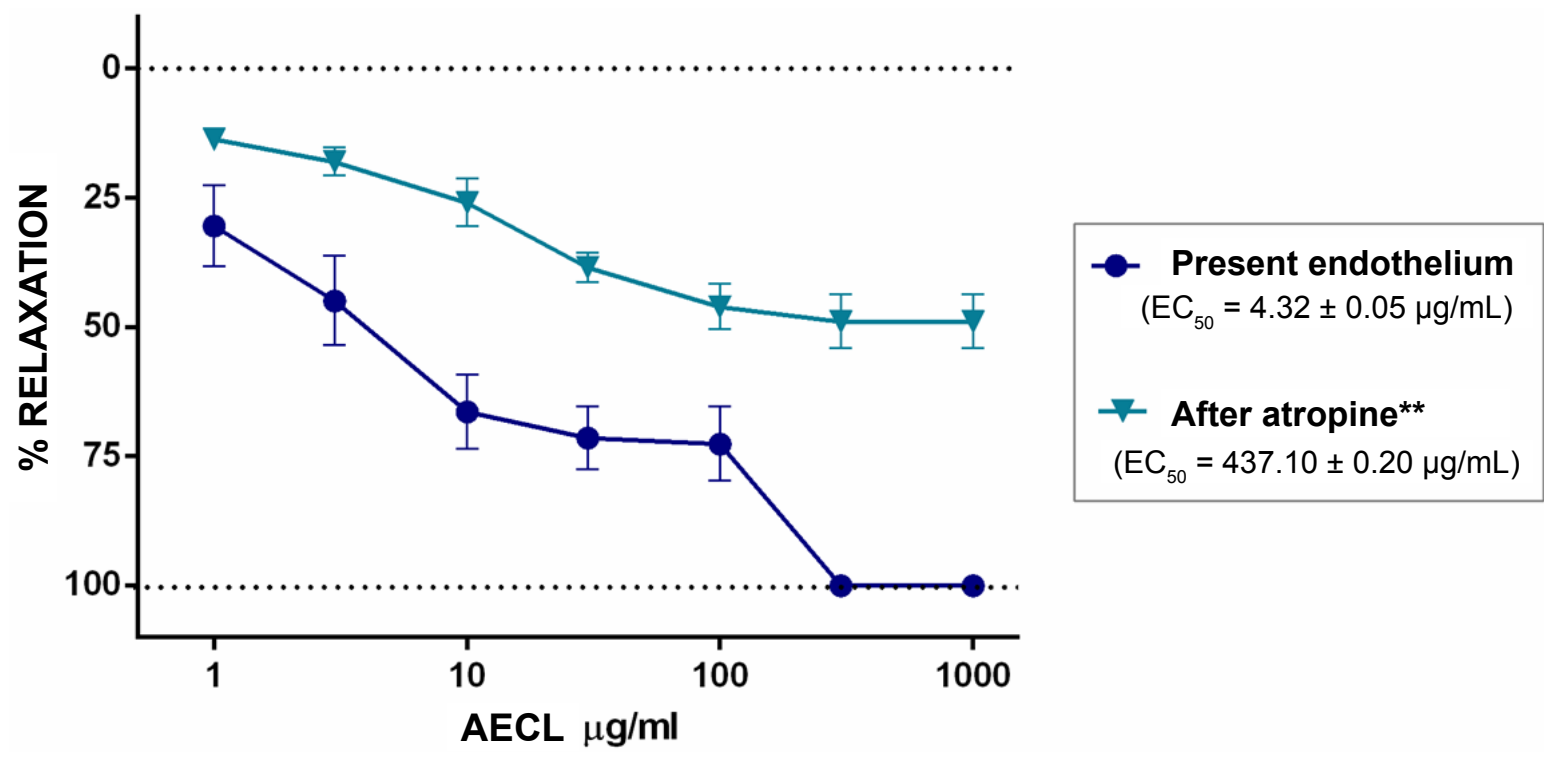

Figure 4 - Concentration-response curve for CLAE $(1,3,10,30,100,300$ and $1000 \mu \mathrm{g} / \mathrm{mL})$ in rat isolated thoracic aorta annulus with intact endothelium and pre-contracted endothelium with PHE $(0.1 \mu \mathrm{M})$ before ( $\mathrm{E}^{+}$control) and after incubation with atropine $(1 \mu \mathrm{M})$. The dots represent the mean \pm SD of the concentrations used with $n=6$ and ${ }^{* *}(p<0.01)$ versus $E^{+}$. 
AECL effect on the contraction caused by blocking the intracellular $\mathrm{K}^{+}$efflux

In annuli without endothelium, although with much less significance, the AECL continued to show a significant vasorelaxant activity $(\mathrm{p}<0.01)$. The AECLinduced response in the isolated thoracic aortic annuli of rats precontracted with $20 \mathrm{mM} \mathrm{KCl}$ was significantly $(\mathrm{p}<0.01)$ lower than the AECL-induced vasorelaxation on PHE-induced contraction in (E-) annuli (Figure 5). The percentage of vasorelaxation over the $20 \mathrm{mM} \mathrm{KCl}$ contraction was $56.98 \%$ and $31.56 \%$, over the $80 \mathrm{mM} \mathrm{KCl}$ contraction. Therefore, it seems that the effect of AECL has a greater significance for the opening of $\mathrm{K}^{+}$channels than for the blockade of voltage-operated calcium channels (VOCCs) (Figure 5).

\section{Discussion}

In the first approach (Figure 1) with ( $\left.\mathrm{E}^{+}\right)$and (E-) annuli, it was observed that the AECL effect strongly depends on factors derived from the vascular endothelium, due to its greater relaxation in $\mathrm{E}^{+}$annuli.

The vascular endothelium, through the layer of cells that covers it internally, produces different mediating substances that regulates the vascular smooth muscle tone. ${ }^{18-23}$ There is a natural control of these mediators' release, and at the limit of the physiological functions, the release of the relaxant factors precedes the contracting agents, ${ }^{19}$ of which NO is the first to be released, followed by prostacyclin and other endothelium-derived relaxant agents. ${ }^{20}$

In many studies, the NO produced by endothelial cells with physiological vasodilation function ${ }^{21,22}$ has been indicated as the main relaxant factor derived from the vascular endothelium. It crosses space from the endothelium to the vascular smooth muscle, promoting the relaxation of this musculature cells, ${ }^{23}$ acting by stimulating the guanylyl cyclase of the cytoplasm soluble fraction, converting Guanosine triphosphate (GTP) into cyclic Guanosine Monophosphate (cGMP), which is the second messenger responsible for the vascular relaxant effect. ${ }^{24}$

In the NO synthesis, first the hydroxylation of one of the guanidine nitrogens of L-arginine occurs to generate NG-hydroxy-L-arginine (NHA), followed by the conversion of NHA into NO and citrulline. ${ }^{25}$ All NOS (Nitric Oxide synthase) isoforms can be inhibited by L-arginine analogs, such as NG-monomethyl-Larginine (L-NMMA), N-imino-ethyl-L-ornithine (L-NIO), NG-amino-L-arginine (L-NAA), NG-nitro-L-arginine

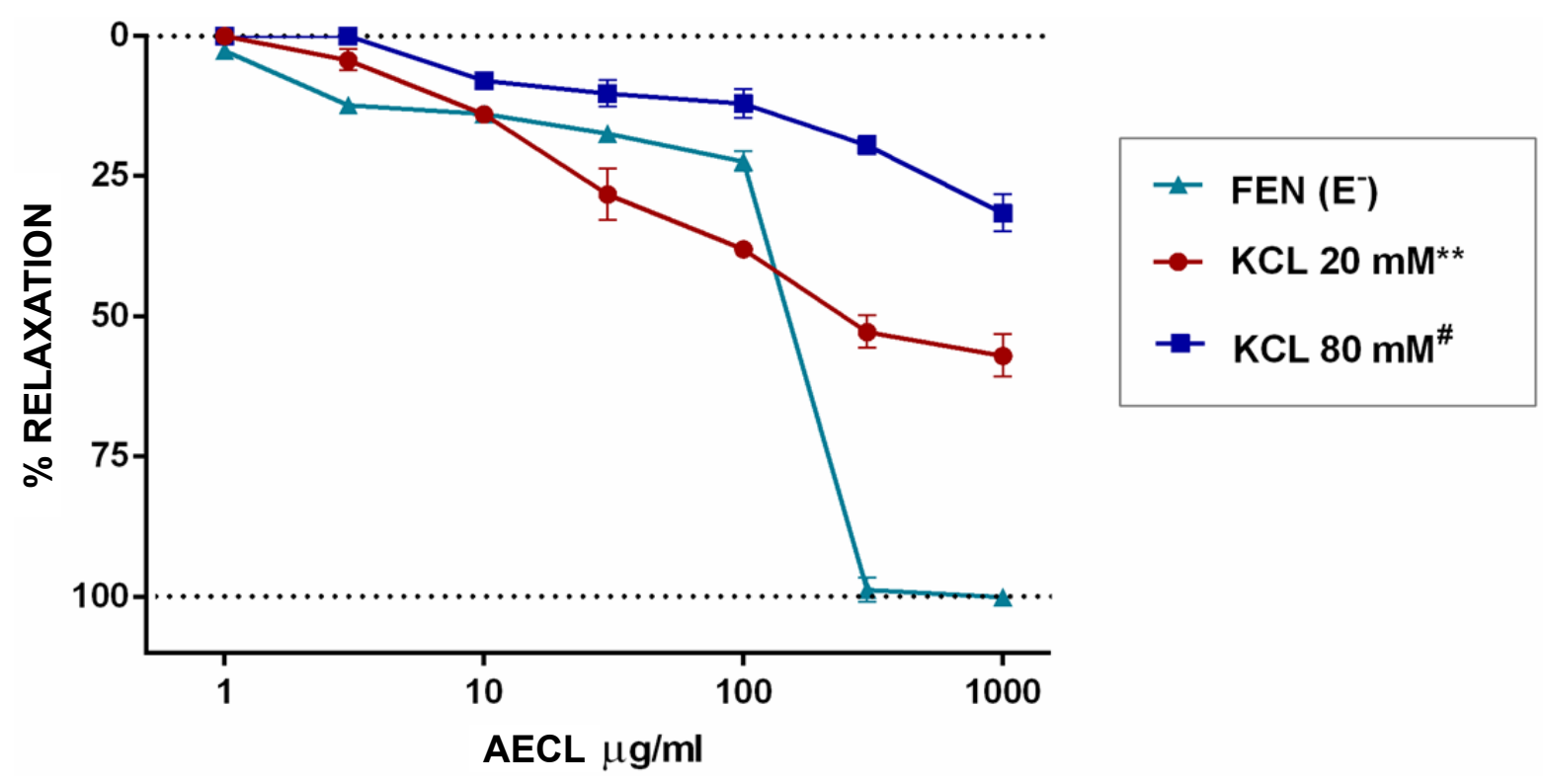

Figure 5 - Concentration-response curve for $\operatorname{CLAE}(1,3,10,30,100,300$ and $1000 \mu \mathrm{g} / \mathrm{mL})$ in rat isolated thoracic aorta annulus without endothelium pre-contracted with PHE, $\mathrm{KCl} 20$ and $\mathrm{KCl} 80$. The dots represent the mean \pm SD of the concentrations used with $\mathbf{n}=6$ and \# $(\mathrm{p}<0.01)$ versus $\mathrm{KCl} 20$. 
(L-NA) and the corresponding methyl ester, NG-nitroL-arginine-methyl ester (L-NAME). ${ }^{26}$ These analogues compete with $\mathrm{L}$-arginine and act as stereospecific inhibitors of NOS. ${ }^{21}$

After the blockade of NO production (Figure 2), it was verified that during the AECL effect there is an important involvement of $\mathrm{NO}$ in the vasorelaxant effect production. In addition to the involvement of NO in the AECL effect, it is scientifically obligatory to investigate the participation of other pathways in relation to the observed effects, especially since it is a crude extract and, thus, a compound consisting of many substances. Therefore, it is possible to suggest that other endothelium-derived vasorelaxant pathways and other independent ones may also be involved in the AECL vasorelaxant activity.

The prostaglandins are synthesized from the arachidonic acid, which is released from the phospholipids of the endothelial cell membrane by the activated phospholipases (A2 and C), and through the action of cyclooxygenase enzymes (COX-1 and COX-2). ${ }^{27}$ Once released, primarily PGI2 and PGE2, they diffuse into smooth muscle cells, promoting the vasorelaxant effect through IP and EP4 receptors, increased cAMP and by reducing intracellular $\mathrm{Ca}^{2+} .28$

The blockade of vasorelaxant prostaglandins synthesis occurs through the inactivation of arachidonic aciddegrading enzymes (COX-1 and COX2). ${ }^{27}$ Indomethacin is a non-selective inhibitor of these prostaglandins. ${ }^{29} \mathrm{In}$ the presence of this blockade and the reduction of the vasorelaxant effect produced by the extract (shown in Figure 3), it is also possible to suggest the involvement of prostaglandins.

The muscarinic receptors are also present in the vascular endothelium; they can be found in many cell types and participate in cell signaling as soon as they are activated by the ligand acetylcholine..$^{30}$ There are five subtypes of muscarinic receptors that are currently accepted, namely M1, M2, M3, M4 and M5, with the M3 receptors being the ones that contribute to smooth muscle contraction, glandular secretion and endothelial NO secretion. It is through the production of endothelial NO that ACh has vasodilatory effects in vivo. ${ }^{31}$ Aiming to verify the involvement of the muscarinic pathway in the AECL relaxant effect, the antagonism of the muscarinic receptors was performed through incubation with atropine, a muscarinic receptor antagonist that acts through competitiveness in these receptors, preventing ACh from binding and exercising its activity. In this approach (Figure 4), where the vasorelaxant response of AECL was more attenuated, muscarinic receptors seem to be the most significantly implicated $(p<0.01)$ in the vasorelaxant effect induced by the AECL in the isolated thoracic aorta of rats.

The relaxant response in annuli (E-) was also important in these approaches to evaluate the possible involvement of ion channels. The activity of $\mathrm{K}^{+}$channels is an essential mechanism for the regulation of the vascular muscle cell membrane potential, being an important determinant of vascular tone. ${ }^{32}$ The opening of a potassium channel present in the membrane of vascular muscle cells causes an increase in ion output, from the intracellular medium into the extracellular medium, causing cell membrane hyperpolarization and then a blockade of voltagedependent $\mathrm{Ca}^{2+}$ channels and a consequent decrease in the input of $\mathrm{Ca}^{2+}$ ions into the intracellular medium, causing vascular relaxation. ${ }^{32,33}$ Conversely, the closing of potassium channels causes a state of depolarization, opening of voltage-dependent $\mathrm{Ca}^{2+}$ channels, increase in intracellular $\mathrm{Ca}^{2+}$ and vasoconstriction. ${ }^{32}$

This mechanism of smooth-muscle relaxation and contraction differs regarding the PHE mechanism of action, which directly stimulates the $\alpha$-adrenergic receptors of the $\mathrm{G}$ protein, acting via phospholipase $\mathrm{C}$, increasing the levels of IP3, and resulting in the release of intracellular $\mathrm{Ca}^{2+}$, causing muscular contraction. ${ }^{34}$

These results, shown in Figure 5, demonstrate that part of the AECL relaxant effect is related to the influence that the extract seems to have on the opening of ion channels, especially $\mathrm{K}^{+}$channels, since the hyperpolarization of the smooth muscle cell membrane can be produced by agents that open the $\mathrm{K}^{+}$channels, leading to the cell's $\mathrm{K}^{+}$efflux. ${ }^{35}$

$\mathrm{K}^{+}$-induced contraction in the aorta seems to be dependent on the influx of $\mathrm{Ca}^{2+}$ through VOCCs, whereas the contraction is inhibited by the removal of $\mathrm{Ca}^{2+}$ from the external environment and by the blockers of these channels. ${ }^{36}$ At the same time that the opening of $\mathrm{Ca}^{2+}$ channels may be required by a membrane depolarization process, the agents that produce membrane hyperpolarization can cause the $\mathrm{Ca}^{2+}$ channels to close, reducing the $\mathrm{Ca}^{2+}$ influx and promoting smooth muscle relaxation. ${ }^{37}$

Ionic channels also seem to be involved in the AECL significant vasorelaxant activity, with a greater expression in the opening of $\mathrm{K}^{+}$channels than in the blockade to VOCCs. 


\section{Conclusion}

The AECL induced an important vasorelaxant effect, being more significant in the presence of the endothelium. The muscarinic pathway seems to be the main one involved with this effect, followed by the NO production pathway, the Prostacyclin's. The opening of $\mathrm{K}^{+}$channels by the AECL, although with a prominently lower degree of participation when compared to the retro-reported pathways, seems to have greater expression than its blockade to VOCCs. AECL showed no evidence of toxicity at the administered concentrations. Further studies are needed on the phytochemistry of AECL, as well as better pharmacological investigation through many other approaches and experimental models, including the use of tools to elucidate the action mechanisms of the extract.

\section{Acknowledgments}

We would like to thank Conselho Nacional de Desenvolvimento Científico e Tecnológico for providing financial support to the project (CNPQ - CNPQ - 407943 / 2013-7). Brozzo, NPM is supported by a scholarship from CAPES.

\section{Author's contribution}

Study Project and Design and writing of the manuscript: Brozzo NPM; data acquisition and Critical review of the

\section{References}

1. Organização Pan-Americana de Saúde. (OPAS). Doenças Cardiovasculares. Brasília (DF);2016. [citado 19 out. 2018]. Disponível em: https: / / www.paho.org/bra/index.php?option=com_content\&vie $\mathrm{w}=$ article\&id=5253:doencas-cardiovasculares\&Itemid $=839$.

2. Braga ADA, Barleta VCN. Alimento funcional: uma nova abordagem terapêutica das dislipidemias como prevenção da doença aterosclerótica. Cadernos UniFOA. 2007;2(3). [citado 19 out. 2018]. Disponível em: https://www.unifoa.edu.br/pesquisa/caderno/ edicao/03/100.pdf

3. Oliveira GMM, Mendes M, Malachias MVB, Morais J, Filho OM, Coelho AS, et al. 2017 Guidelines for the management of arterial hypertension in primary health care in portuguese-speaking countries. Rev Port Cardiol. 2017;36(11):789-98.

4. Fonteneles JL, Santos ZMSA, Silva MP. Estilo de vida de idosos hipertensos institucionalizados: análise com foco na educação em saúde. Revista da Rede de Enfermagem do Nordeste. RENE. 2009;10(3):53-60.

5. Martelli A, Longo MAT, Seriane C. Clinical aspects and action mechanism of main pharmacological classes used in the treatment of hypertension. Estud Biol. 2008:30(70/71/72):149-56. manuscript regarding important intellectual content: Brozzo NPM, Cunha RM, Meneguetti DUO. Data analysis and interpretation: Brozzo NPM, Cunha RM, Silva EF, Silva DA. Statistical analysis: Brozzo NPM, Gonçalves EA. Financial support provision: Cunha RM.

\section{Potential Conflict of Interest}

No potential conflict of interest relevant to this article was reported.

\section{Sources of Funding}

This study was partially funded by CNPq.

\section{Study Association}

This article is part of the thesis of master submitted by Natacha Pinheiro Melo Brozzo, from Universidade Federal do Acre.

\section{Ethics approval and consent to participate}

This study was approved by the Ethics Committee on Animal Experiments of the Universidade Federal do Acre under the protocol number 23107.018498.
6. Barbosa MO, Lacerda GM, Alves DA, Oliveira CJ, Kerntopf MR, Fernandes GP. Use of natural resources for the treatment of diabetes and hypertension in traditional communities. R Interd. 2017;10(2):125-31.

7. Souza JBP, Ataliba FJB, Costa DA, Farias, AD. Interações planta medicinal $x$ medicamento convencional no tratamento da hipertensão arterial. Infarma Ciências Farmacêuticas. 2017;29(2):90-9.

8. Chainani-Wu N. Safety and anti-inflammatory activity of curcumin: a component of tumeric (Curcuma longa). J Altern Complement Med. 2003;9(1):161-8.

9. Pintão AM, Silva IF. A verdade sobre o açafrão. In: Workshop Plantas Medicinais e Fitoterapêuticas nos Trópicos; 29-31 out 2008; Portugal. Portugal: IICT/CCCM; 2008. p. 1-19.

10. Ghorbanzadeh V, Mohammadi M, Dariushnejad H, Abhari A, Chodari L, Mohaddes G. Cardioprotective effect of crocin combined with voluntary exercise in rat: role of Mir-126 and Mir-210 in heart angiogenesis. Arq Bras Cardiol. 2017;109(1):54-62.

11. Jurenka JS. Anti-inflammatory properties of curcumin, a major constituent of Curcuma longa: a review of preclinical and clinical research. Altern Med Rev. 2009;14(2):141-53. 
12. Araújo CC, Leon LL. Biological activities of Curcuma longa L. Mem Inst Oswaldo Cruz. 2001;96(5):723-8.

13. Toda S, Miyase T, Arichi H, Tanizawa H, Takino Y. Natural antioxidants. III. Antioxidative components isolated from rhizome of Curcuma longa L. Chem Pharm Bull. 1985;33(4):1725-8.

14. Apisariyakul A, Vanittanakom N, Buddhasukh D. Antifungal activity of turmeric oil extracted from Curcuma longa (Zingiberaceae). J Ethnopharmacol. 1995;49(3):163-9.

15. Adamayore OA, Anjos RM, Almeida MM, Veras RC, Silvia DF, Oliveira FA, et al. Hypotensive and endothelium-independent vasorelaxant effects of methanolic extract from Curcuma longa L. in rats. J Ethnopharmacol. 2009;124(3):457-62.

16. Organization for Economic Co-operation and Development (OECD). Acute Oral Toxicity- Acute Toxic Class Method. Eleventh Addendum to the OECD guidelines for the testing of chemicals. Paris; 2001.

17. Malone $\mathrm{MH}$, Robichaud RC. A hippocratic screen for pure or crude drug materials. Lloydia. 1962;25(4):320-32.

18. Ceballos G; Gutiérrez-Salmeán G, Meaney E. The vascular endothelium: a review series I. Basic aspects of the vascular endothelium. Rev Mex Cardiol. 2015;26(2):95-100.

19. Pinto WJ, Areas MA, Reyes FGR. Óxido nítrico e o sistema vascular: uma revisão. Acta Cient Biol Saúde. 2003;5(1):47-61.

20. Batlouni M. Endotélio e hipertensão arterial. Rev. Bras. Hipertens. 2001;8(3):328-38.

21. Dusse LMS, Vieira LM, Carvalho MG. Revisão sobre óxido nítrico. J Bras Patol Med Lab. 2003;39(4):435-50.

22. Jeddi S, Asl AN, Asgari A, Ghasemi A.The effect of sleep deprivation on cardiac function and tolerance to ischemia-reperfusion injury in male rats. Arq Bras Cardiol. 2016;106(1):41-8.

23. Potje SR. Efeito vasorelaxante do doador de óxido nítrico [Ru (terpy)(bdq) NO] 3+(TERPY) em artéria de resistência e sua interação com a óxido nítrico sintase endotelial (eNOS) de ratos espontaneamente hipertensos (SHR) [Tese]. Araçatuba (SP): Universidade Estadual Paulista Julio de Mesquita ; 2016.

24. Cabral JE, Belik J. Persistent pulmonary hypertension of the newborn: recent advances in pathophysiology and treatment. J Pediatr. 2013;89(3):226-42.

25. Flora Filho R, Zilberstein B. Óxido nítrico: o simples mensageiro percorrendo a complexidade. Metabolismo, síntese e funções. Rev Assoc Med Bras. 2000;46(3):265-71.
26. Maggi C A, Barbanti G, Turini, D, Giuliani S. Effect of NG-monomethyl L-arginine (L-NMMA) and NG-nitro L-arginine (L-NOARG) on nonadrenergic non-cholinergic relaxation in the circular muscle of the human ileum. Br J Pharmacol. 1991;103(4):1970-2.

27. Batlouni M. Nonsteroidal anti-inflammatory drugs: cardiovascular, cerebrovascular and renal effects. Arq Bras Cardiol. 2010;94(4);556-63.

28. Andre E. Análise dos mecanismos envolvidos no relaxamento induzido pelo sesquiterpeno poligodial em vasos de coelho e cobaia e no corpo cavernoso de coelho in vitro [Dissertação]. Florianópolis (SC): Universidade Federal de Santa Catarina; 2000.

29. Rodwell VW, Bender DA, Botham KM, Kennelly PJ, Weil PA. Harper's illustrate biochemistry. 30th ed. New York: McGraw Hill Global; 2015.

30. Rodrigues LU, Soares CT, Venuto D.B, Santana RG, Xavier AR, Silva Junior CT, et al. Muscarinic receptors and chronic obstructive pulmonary disease: from biology to clinical practice. Rev Med. 2016;95(3):128-32

31. Vieira AM. Eficácia do extrato aquoso de maytenus rigida mart. (celastraceae) na lesão gástrica induzida por etanol em camundongos: análise do envolvimento de óxido nítrico, prostaglandinas, receptores opioides e $\alpha$-2-adrenérgicos [Dissertação]. Sobral (CE): Universidade Federal do Ceará; 2013.

32. Golan DE, Tashjian AH, Armstrong EJ, Armstrong AW. Princípios de farmacologia: a base fisiopatológica da farmacoterapia. 2a ed. Rio de Janeiro: Guanabara Koogan; 2009.

33. Veloso CC, Soares GL, Perez AC, Rodrigues VG, Silva FC. Pharmacological potential of Maytenus species and isolated constituents, especially tingenone, for treatment of painful inflammatory diseases. Rev Bras Farmacogn. 2017;27(4):533-40.

34. Chioca LR, Segura RCF, Andreatini R, Losso EM. Antidepressants and local anesthetics: drug interactions of interest to dentistry. Rev Sul-Bras Odontol. 2010;7(4):466-73.

35-Silva AS, Zanesco A. Physical exercise, B-adrenergic receptors, and vascular response. J Vasc Bras. 2010;9(2):47-56.

36. Kuriyama H, Kitamura K, Nabata H. Pharmacological and physiological significance of ion channels and factors that modulate them in vascular tissues. Pharmacol Rev. 1997;47(3):387-573.

37. Faraci FM, Heistad DD. Regulation of the cerebral circulation: role of endothelium and potassium channels. Physiol Rev. 1998;78(1):53-97. 